\title{
Central Serous Chorioretinopathy Induced by Work Stress: A Case Report
}

\author{
Ade J. Nursalim, Vera Sumual
}

Department of Ophthalmology, Prof. Dr. R. D. Kandou Central General Hospital, Manado

Email: dr.adejn@gmail.com

\begin{abstract}
Abstrak: Central serous chorioretinopathy (CSC) adalah terkumpulnya cairan serosa di bawah lapisan epitel pigmen retina yang mengakibatkan terlepasnya retina neurosensorik (detachment). Keadaan ini dapat disebabkan oleh berbagai faktor risiko, termasuk stres psikologik. Jenis kelamin laki-laki merupakan salah satu faktor risiko CSC. Terapi kondisi psikologik merupakan penanganan utama CSC yang diinduksi oleh stres kerja. Kami melaporkan seorang laki-laki berusia 27 tahun yang datang ke Poliklinik Mata RSUP Prof. Dr. R. D. Kandou Hospital dengan keluhan kekaburan mata kanan yang mendadak sejak seminggu lalu tanpa didahului oleh nyeri pada mata. Pasien juga mengalami kesulitan dalam membaca teks dan mengenali wajah bila hanya menggunakan mata kanannya. Pasien telah pergi ke optik tetapi tidak mendapatkan ukuran kacamata yang sesuai. Pasien bekerja sebagai tenaga administrasi dan akhir-akhir ini mendapatkan beban kerja berlebihan. Pasien mengakui bahwa ia mengalami kesulitan dalam mengatur aktivitasnya, dan merasakan kelelahan sepanjang hari serta kehilangan minat kerja. Hasil pemeriksaan mata mendapatkan visus 6/15 untuk mata kanan dan visus 6/6 untuk mata kiri, dan metamorphopsia sedangkan hasil pemeriksaan oftalmoskopi memperlihatkan adanya edema dengan lingkaran kekuningan dan berbatas tidak jelas pada mata kanan. Pemeriksaan lanjut dengan OCT menunjukkan adanya cairan subretinal pada mata kanan disertai terlepasnya lapisan epitel pigmen. Saat kontrol setelah 36 hari, visus mata kanan telah membaik 6/6F2 dan pemeriksaan OCT menunjukkan penurunan tebal makula dari $289 \mu \mathrm{m}$ pada kunjugan pertama menjadi $190 \mu \mathrm{m}$, serta tidak tampak adanya cairan subretinal. Simpulan kasus ini ialah central serous chorioretinopathy yang diinduksi oleh stres kerja, dengan penanganan utama ialah terapi psikologik untuk memperbaiki kualitas hidup.
\end{abstract}

Kata kunci: central serous chorioretinopathy (CSC), stres kerja

\begin{abstract}
Central serous chorioretinopathy (CSC) is a condition where serous fluid builds up in the retinal pigment epithelium layer which causes neurosensory retinal detachment. This condition is affected by many risk factors, including psychological stress. Male gender is one of the risk factors for CSC. Treatment to the patient's psychological condition can be the main therapy in handling CSC induced by work stress. We reported a 27 -year-old male came to the eye clinic at Prof. dr. R. D. Kandou Hospital complaining of sudden blurred vision in his right eye a week ago without initial pain in the eye. The patient also experienced difficulty in reading text and recognizing people's face using the right eye. The patient went to an optic store but he did not find suitable glasses. The patient works as an administrative employee and is currently getting a heavy workload at his workplace. The patient admitted that he had issues in managing his life in a day. Patients felt tired throughout the day and had no interest in making any activities. The results of the eye examination showed vision 6/15 in the right eye and 6/6 in the left eye, metamorphopsia, edema with a yellowish circle with an unclear border on the right eye using ophthalmoscopy examination, and a subretinal fluid image in the patient's right eye with epithelial detachment pigment acquired through the examination with OCT. After 36 days from the first visit, the right eye vision was improved to 6/6 F2 and OCT examination resulted in a decrease in macula thickness from $289 \mu \mathrm{m}$ at the first visit to $190 \mu \mathrm{m}$, and there was no subretinal fluid. In conclusion, this was a CSC case induced by work stress, and the main treatment was psychological therapy in order to improve the quality of life (QoL).
\end{abstract}

Keywords: central serous chorioretinopathy (CSC), work stress 


\section{INTRODUCTION}

Central serous chorioretinopathy (CSC) is a condition where serous fluid builds up under the retinal pigment epithelium layer which causes neurosensory retinal detachment. It has various causes and is usually related to people of middle age. Psychic stress is known to be a risk factor for CSC in addition to other risk factors such as type $\mathrm{A}$ personality; narcissistic personality; work stress; corticosteroid therapy; post vitrectomy surgery; heart, spinal cord, kidney, and marrow transplants; conditions involving cortisol such as Cushing disease and pregnancy; hypertension; sleep apnea; smoking; alcohol consumption; antihistamines; asthma; and gastroesophageal reflux (GERD). ${ }^{1}$ The influence of psychic stress is also strongly worsen by individual coping responses in dealing with psychological stress. ${ }^{2}$ Psychic stress itself has been an issue for many patients. A decrease in vision ability that occurs due to CSC may able to aggravate the stress and reduce the patient's quality of life. ${ }^{3}$

Worth notice is that CSC is the fourth non-surgical retinopathy after age-related macular degeneration, diabetic retinopathy, and branch retinal vein occlusion. ${ }^{4}$ It is more frequent in males than in females with a ratio of $8: 1 .^{5,6}$

The following will be the case of a 27year-old male who came with a blurred vision complaint and was diagnosed as CSC. The risk factor in this case was work stress.

\section{CASE REPORT}

A 27-year-old male came to the eye clinic at Prof. Dr. R. D. Kandou Hospital with a sudden blurred vision complaint in his right eye a week ago without initial pain in the eye. The patient also experienced difficulty in reading text and recognizing people's face if just using his right eye; therefore, he went to the optic store but did not find suitable glasses. The patient worked as an administrative employee and currently got much heavier workload. The patient admitted that he had issues in managing his life in a day, felt tired throughout the day, and had no interest in making any activities. There was no history of high blood pressure, diabetes, or high cholesterol level. The patient used to do exercise such as jogging regularly but had stopped since 2 months ago due to the overload job. The patient had a wife and two children of 6 and 3 years old.

The ophthalmological examination obtained $6 / 15$ right eye vision and $6 / 6$ left eye vision. The field-view examination with confrontation indicated that there was no peripheral visual field disturbance. Examination with Goldmann perimetry revealed central scotoma in the right eye and normal visual field in the left eye. The intraocular pressure of the right eye was $14 \mathrm{~mm} \mathrm{Hg}$ and of the left eye was $13 \mathrm{~mm} \mathrm{Hg}$. Further posterior segment examination using indirect ophthalmoscopy with a $20 \mathrm{D}$ lens resulted in, as follows: the posterior segment of the right eye showed a uniform fundus reflex, optic nerve papillary border, vital color, and $0.3 \mathrm{cdr}$; the right eye retina showed edema with a yellowish circle and a less clear boundary; and a normal fundus for the left eye. The patient was consulted for an Optical Coherence Tomography (OCT) examination which resulted in subretinal fluid image in the right eye with epithelial pigment detachment (Fig. 1).

Based on all performed examinations, the patient was diagnosed as central serous chorioretinopathy in the right eye with repair, and emetropia in the left eye.

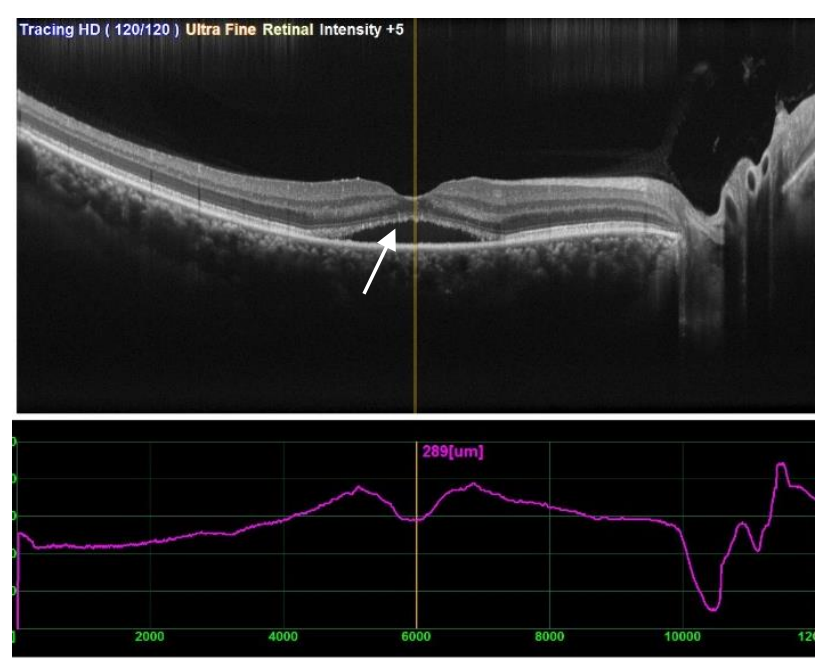

Figure 1. OCT examination on the patient's right eye revealed subretinal fluid image with epithelial pigment detachment; macula thickness $289 \mu \mathrm{m}$ 
The patient was treated with B6 vitamin three tablets a day and was also educated about the influence of stress and to manage the perceived workload. Moreover, he was given the opportunity to share his encountered problems and to discuss the possible solutions.

At 36 days later the patient returned to the eye clinic. He felt that his right eye's vision was improved. The loss of vision field in the patient's eyes had disappeared. Stress management strategy that was applied by the patient was doing charity activities. He was participated in voluntary groups of helping disaster victims in several affected areas. Since then, he felt free of worry and was motivated for life's challenges. The results of the examination showed right eye vision $6 / 6 \mathrm{~F} 2$ pinhole $6 / 6$ and left eye 6/6. Right and left eye intraocular pressures were $15 \mathrm{~mm} \mathrm{Hg}$. Amsler grid check showed no metamorphopsia. The posterior segment examination showed a normal fundus. OCT examination resulted in a decrease in macula thickness from 289 $\mu \mathrm{m}$ at the first visit to $190 \mu \mathrm{m}$, and there was no subretinal fluid.

The patient was diagnosed as CSC in the right eye with repair and emetropia in the left eye. He was treated with vitamin B6 three times a day, and was also educated to maintain his psychological mental condition.
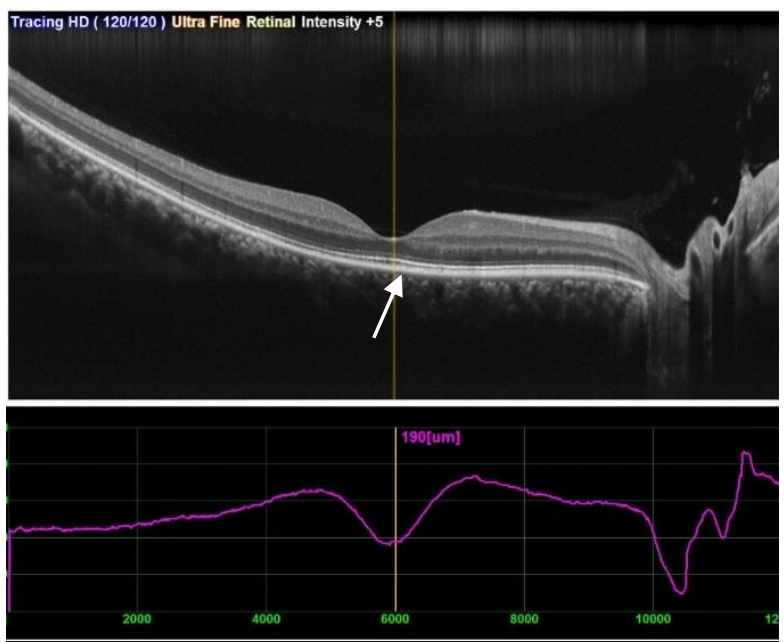

Figure 2. OCT examination on the patient's right eye after 36 days revealed no subretinal fluid; macula thickness $190 \mu \mathrm{m}$

\section{DISCUSSION}

The patient in our case is a male of 27 years old. Males are known to have a higher prevalence for CSC than females with a ratio of $8: 1,5,6$ and $72-88 \%$ of CSC patients are male. ${ }^{7}$ As aforementioned, stress risk factor is strongly related to the increase of CSC cases. $^{2}$

Disorders in choriocapillary function, choroid hyperpermeability, and abnormal choroid thickness are the main pathologies in CSC cases. ${ }^{8}$ Stress condition can lead to an increase in the cortisol hormone which further causes a decrease in choroid function and an increase in intraluminal pressure in the choroid capillaries around the macula which results in extravasation of serum and tamponade of the blood vessels. In concert of all of these, accumulation of fluid occurs which eventually ends with CSC. ${ }^{9,10}$

People with work stress need to get knowledge about this disease. In severe condition, collaboration with the psychiatric department can be considered in order to get serotonin reuptake inhibitors. ${ }^{9}$ People who work compulsively have a higher tendency to experience work stress. This work habit is in line with type A personality which is a combination of characters such as being impatient, always on time, paying attention to status, very competitive, aggressive, and difficult to relax. People with type A personality tend to be workaholic, multitasking, set a time limit for themselves, and are also not happy if there is a delay. Without good handling, people with type A personality can show insecurity or lack of confidence even though they do not appear outside. Stressful work conditions with CSC reduce the quality of life (QoL) of the patient. $^{11}$

Working and not working are equally giving mental burden on anyone. However, people who had no job have a higher risk of experiencing stress condition. In our case, the patient claimed to have a heavy workload and then he chose to be a volunteer in helping victims of natural disasters as a coping mechanism for stress. Social support has a positive impact on improving one's mental status. ${ }^{12}$ A national survey in Austra- 
lia found that people with high-quality social relationships between friends and family have less tendency to experience depression. Those who do not have family support or friends have 3 times more risk of depression than those who have family or friends' support. ${ }^{13}$ The choice to provide assistance to disaster victims was quite effective for this patient in dealing with stress.

Medical therapy in this patient was B6 vitamin (pyridoxine). This vitamin was chosen as a therapy for a placebo effect. The recommended dose of pyridoxine is $1-25 \mathrm{mg}$ per day. Provision of pyridoxine $250 \mathrm{mg}$ per day in the long term can interfere with the skin, digestive tract, and nervous system. Pyridoxine is needed as a coenzyme in various reactions in amino acid, carbohydrate and lipid metabolism. Neuropathic effects on pyridoxine toxicity can occur in several forms, such as hypoesthesia, paraesthesia, peripheral neuropathy, ${ }^{14}$ muscle weakness, impaired walking and balance, and other complaints. ${ }^{15}$

The monitoring results on the 36th day showed significant changes in the patient's vision and findings on physical examination. Acute CSC is a self-healing condition. On average retinal pigment epithelium can be re-attached within 3-4 months. In this patient, stress condition could be overcome properly. The delineation of risk factors helped significantly in improving the patient's condition. ${ }^{1}$

\section{CONCLUSION}

We reported a central serous chorioretinopathy (CSC) case in a 27-year-old male complaining of sudden blurred vision in his right eye a week ago. The diagnosis of CSC was based on anamnesis, ophthalmological examination, funduscopic examination, and OCT examination which revealed subretinal fluid in the right eye associated with retinal epithelial pigment detachment. The treatment performed was B6 vitamin tablet three times a day. Moreover, the patient was educated in managing the perceived workload and was given the opportunity to discuss his problems. The solution chosen by this patient was to provide assistance to natural disaster victims. The patient's vision and QoL improved in 36 days of therapy.

\section{Conflict of interest}

The authors affirm no conflict of interest in this study.

\section{REERENCES}

1. Lam D, Das S, Liu S, Lee V, Lu Lin. Central serous chorioretinopathy. In: Schachat AP, editor. Ryan's Retina (6th ed). China: Elsevier, 2018; p. 1465-83.

2. Lahousen T, Painold A, Luxenberger W, Schienle A, Kapfhammer HP, Ille R. Psychological factors associated with acute and chronic central serous chorioretinopathy. Nord J Psychiatry. 2016; 70(1):24-30.

3. Şahin A, Bez Y, Kaya MC, Türkcü FM, Şahin M, Yüksel H. Psychological distress and poor quality of life in patients with central serous chorioretinopathy. Semin Ophthalmol. 2014;29(2):73-6.

4. Wang M, Munch IC, Hasler PW, Prünte C, Larsen M. Central serous chorioretinopathy. Acta Ophthalmologica. 2008; 86(2):126-45.

5. Liegl R, Ulbig MW. Central serous chorioretinopathy. Ophthalmologica. 2014; 232(2):65-76.

6. Riaz MT. Different patterns of central serous chorio-retinopathy on fundus fluorescein angiography. In: Islamabad Congress of Ophthalmology. 2017;15(2):65.

7. Spaide RF, Campeas L, Haas A, Yannuzzi LA, Fisher YL, Guyer DR, et al. Central serous chorioretinopathy in younger and older adults. Ophthalmology. 1996;103 (12):2070-80.

8. American Academy of Ophthalmology. Section 12: Retina and vitreous. Italy: American Academy of Ophthalmology, 2014; p. 171-6.

9. Conrad R, Geiser F, Kleiman A, Zur B, Karpawitz-Godt A. Temperament and character personality profile and illnessrelated stress in central serous chorioretinopathy. The Scientific World Journal. 2014;631687:1-7.

10. Gemenetzi M, De Salvo G, Lotery AJ. Central serous chorioretinopathy: an update on pathogenesis and treatment. Eye. 2010; 24(12):1743-56. 
11. Şahin A, Bez Y, Kaya MC, Türkcü FM, Şahin M, Yüksel H. Psychological distress and poor quality of life in patients with central serous chorioretinopathy. Semin Ophthalmol. 2014;29(2):73-6.

12. Crowe L, Butterworth P. The role of financial hardship, mastery and social support in the association between employment status and depression: results from an Australian longitudinal cohort study. BMJ open. 2016;6(5):e009834.

13. Werner-Seidler A, Afzali MH, Chapman C, Sunderland M, Slade T. The relationship between social support networks and depression in the 2007 National Survey of Mental Health and Well-being. Soc Psychiatry Psychiatr Epidemiol. 2017; 52(12):1463-73.

14. Bacharach R, Lowden M, Ahmed A. Pyridoxine toxicity small fiber neuropathy with dysautonomia: a case report. J Clin Neuromuscul Dis. 2017;19(1):43-6.

15. Van Hunsel F, van de Koppel S, van Puijenbroek E, Kant A. Vitamin B6 in health supplements and neuropathy: case series assessment of spontaneously reported cases. Drug Safety. 2018;41(9): 859-69. 